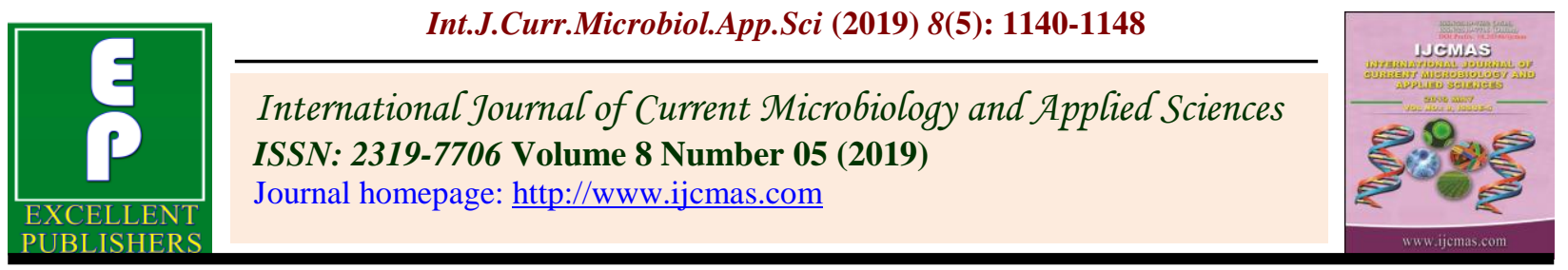

Original Research Article

https://doi.org/10.20546/ijcmas.2019.805.129

\title{
Effect of Integrated Nitrogen Management on Soil Properties and Yield of Wheat in Salt Affected Soil
}

\author{
S.K. Tripathi* \\ Department of Soil Science and Agricultural Chemistry, Kulbhasker Ashram P.G. College, \\ Prayagraj-211001 (U.P.), India \\ *Corresponding author
}

\section{A B S T R A C T}

\begin{tabular}{|l|}
\hline Ke y w o r d s \\
Integrated nutrient \\
management, Soil \\
properties, Salt \\
affected soil, Yield, \\
wheat
\end{tabular}

\section{Introduction}

Wheat (Triticum aestivum L.) is second important food grains crop being consumed next to rice and contributes to extent by of 20 percent of food grains (Patel et al., 2017). The stagnation in production of food grains for the past few years has become a matter of concern and is posing a serious threat to our national food security. Soil health degradation in cultivated areas is manifested in terms of loss of soil organic matter, depletion of native soil fertility due to imbalance and unscientific use of fertilizer, which is now major cause in improving crop productivity.
Salt affected soils which occupy 7.0 million hectares in India, Its maximum area in north India, only in U.P. 13 lakh ha (Singh, 2008). These soils have excess soluble salts or exchangeable $\mathrm{Na}^{+}$or both in root zone. Soils are extremely poor in organic carbon, available nitrogen and zinc. Crops are grown on these soils invariably suffers from nutritional disorder resulting low yields. The tremendous losses of applied nitrogen from these soils are major problem due to high $\mathrm{pH}$, ESP and dominance of carbonate, bicarbonate and hydroxyl ions. The integrated plant nutrient supply system, by which we can apply the nutrient in balanced form, is emerging as the most logical concept for 
managing and sustaining long term soil fertility and productivity. INM which entails the maintenance of sail fertility to an optimum level for crop productivity to obtain the maximum benefit from all possible sources of plant nutrients both organics as well as inorganics in an integrated manner (Aulakh and Grant, 2008), is an essential step to address the twin concern of nutrient excess and nutrient depletion. Organic sources such as FYM, Pressmud and water hyacinth play an important role in improvement of soil fertility and sustaining crop productivity in long run. The present investigation was therefore, undertaken to study the effect of integrated nitrogen management on soil properties and yield of wheat in salt affected soil.

\section{Materials and Methods}

Field experiment was conducted at the Instructional farm of Narendra Deva University of Agriculture and Technology, Narendra Nagar (Kumarganj), Faizabad during rabi season.

\section{Details of treatments}

\begin{tabular}{|c|c|c|}
\hline S. No. & Details of Treatment & Symbol used \\
\hline $\mathbf{T}_{1}$ & Control & Control \\
\hline $\mathbf{T}_{2}$ & $\begin{array}{l}\text { Recommended } \\
\left.\text { 120:60:40:25 (N, P, K, } \mathrm{ZnSO}_{4}\right) \mathrm{kg} \mathrm{ha}^{-1}\end{array}$ & $\begin{array}{l}\text { Recommended } \\
\text { (NPK Zn) }\end{array}$ \\
\hline $\mathbf{T}_{\mathbf{3}}$ & $\begin{array}{l}90 \mathrm{~kg} \mathrm{~N} \mathrm{ha}^{-1} \text { through urea }+30 \mathrm{~kg} \mathrm{~N} \mathrm{ha}^{-1} \\
\text { through farm yard manure }\end{array}$ & $\mathrm{U}-\mathrm{N}_{90}+\mathrm{FYM}-\mathrm{N}_{30}$ \\
\hline $\mathbf{T}_{4}$ & $\begin{array}{l}60 \mathrm{~kg} \mathrm{~N} \mathrm{ha}^{-1} \text { through urea }+60 \mathrm{~kg} \mathrm{~N} \mathrm{ha}^{-1} \\
\text { through farm yard manure }\end{array}$ & $\mathrm{U}-\mathrm{N}_{60}+\mathrm{FYM}-\mathrm{N}_{60}$ \\
\hline $\mathbf{T}_{5}$ & $\begin{array}{l}30 \mathrm{~kg} \mathrm{~N} \mathrm{ha}^{-1} \text { through urea }+90 \mathrm{~kg} \mathrm{~N} \mathrm{ha}^{-1} \\
\text { through farm yard manure }\end{array}$ & $\mathrm{U}-\mathrm{N}_{30}+\mathrm{FYM}-\mathrm{N}_{90}$ \\
\hline $\mathbf{T}_{6}$ & $\begin{array}{l}90 \mathrm{~kg} \mathrm{~N} \mathrm{ha}^{-1} \text { through urea }+30 \mathrm{~kg} \mathrm{~N} \mathrm{ha}^{-1} \\
\text { through pressmud }\end{array}$ & $\mathrm{U}-\mathrm{N}_{90}+\mathrm{PM}-\mathrm{N}_{30}$ \\
\hline $\mathbf{T}_{7}$ & $\begin{array}{l}60 \mathrm{~kg} \mathrm{~N} \mathrm{ha}^{-1} \text { through urea }+60 \mathrm{~kg} \mathrm{~N} \mathrm{ha}^{-1} \\
\text { through pressmud }\end{array}$ & $\mathrm{U}-\mathrm{N}_{60}+\mathrm{PM}-\mathrm{N}_{60}$ \\
\hline $\mathbf{T}_{8}$ & $\begin{array}{l}30 \mathrm{~kg} \mathrm{~N} \mathrm{ha}^{-1} \text { through urea }+90 \mathrm{~kg} \mathrm{~N} \mathrm{ha}^{-1} \\
\text { through pressmud }\end{array}$ & $\mathrm{U}-\mathrm{N}_{30}+\mathrm{PM}-\mathrm{N}_{90}$ \\
\hline $\mathbf{T}_{9}$ & $\begin{array}{l}90 \mathrm{~kg} \mathrm{~N}^{-1} \text { through urea }+30 \mathrm{~kg} \mathrm{~N} \mathrm{ha}^{-1} \\
\text { through water hyacinth }\end{array}$ & $\mathrm{U}-\mathrm{N}_{90}+\mathrm{WH}-\mathrm{N}_{30}$ \\
\hline $\mathbf{T}_{10}$ & $\begin{array}{l}60 \mathrm{~kg} \mathrm{~N} \mathrm{ha}^{-1} \text { through urea }+60 \mathrm{~kg} \mathrm{~N} \mathrm{ha}^{-1} \\
\text { through water hyacinth }\end{array}$ & $\mathrm{U}-\mathrm{N}_{60}+\mathrm{WH}-\mathrm{N}_{60}$ \\
\hline $\mathbf{T}_{11}$ & $\begin{array}{l}30 \mathrm{~kg} \mathrm{~N} \mathrm{ha}^{-1} \text { through urea }+90 \mathrm{~kg} \mathrm{~N} \mathrm{ha}^{-1} \\
\text { through water hyacinth }\end{array}$ & $\mathrm{U}-\mathrm{N}_{30}+\mathrm{WH}-\mathrm{N}_{90}$ \\
\hline
\end{tabular}

The experiment was laid out in Randomized Block Design (RBD) with three replications. The soil of the Instructional Farm of the university where the experiment was conducted was alkaline which exhibits $\mathrm{pH}$ values in 8.8-8.9. Pressmud, FYM and chopped water hyacinth were applied two weeks before sowing of wheat. Fertilizers viz. nitrogen, phosphorus, potassium and zinc were applied in the forms of Urea, DAP,
Muriate of Potash and Zinc Sulphate respectively. $\mathrm{P}_{2} \mathrm{O}_{5}$ and $\mathrm{K}_{2} \mathrm{O}$ were applied at the rate of 60 and $40 \mathrm{~kg} \mathrm{ha}^{-1}$ respectively, uniformly to all the treatments. The zinc was applied as $\mathrm{ZnSO}_{4}$ at the rate of $25 \mathrm{~kg} \mathrm{ha}^{-1}$ in treatment receiving only chemical fertilizers. The nitrogen was applied through urea and organic sources as per treatment. The half of urea nitrogen in all the treatments was applied at the time of sowing. Remaining half amount 
of nitrogen was applied as top dressing after first irrigation of wheat crop. The wheat cultivar NW-1014 was taken as a test crop. Surface soil samples $(0-15 \mathrm{~cm})$ were collected at harvest of crop. Soil samples were analyzed for $\mathrm{pH}, \mathrm{EC}, \mathrm{ESP}$, hydraulic conductivity, available NPK and $\mathrm{Zn}$ as per standard methods.

\section{Results and Discussion}

\section{Grain yield}

The date embodied in table 1 and figure 1 indicated that grain yield of wheat increased significantly in all treated plots as compared to control during both the years. The yield was higher with pressmud followed by FYM and water hyacinth. The treatment $\mathrm{T}_{7}\left(\mathrm{UN}_{60}+\right.$ PM- $\left.\mathrm{N}_{60}\right)$ produced highest grain yield (40.70 and $42.20 \mathrm{q} \mathrm{ha}^{-1}$ ) which was significantly superior ever treatments $T_{1}$ (control), $T_{2}, T_{5}$, $\mathrm{T}_{8}$ and $\mathrm{T}_{11}$. On the basis of grain yield, various treatments can be arranged in this order, $\mathrm{T}_{7}>\mathrm{T}_{4}>\mathrm{T}_{10}>\mathrm{T}_{6}>\mathrm{T}_{3}>\mathrm{T}_{9}>\mathrm{T}_{8}>\mathrm{T}_{5}>$ $\mathrm{T}_{11}>\mathrm{T}_{2}>\mathrm{T}_{1}$. Application of $60 \mathrm{~kg} \mathrm{~N}$ through chemical fertilizer and $60 \mathrm{~kg} \mathrm{~N}$ through pressmud produced maximum crop yields than other treatments, because of its greater role in soil improvement. Pressmud is excellent source of major nutrient (N.P.K.Ca) and micronutrient (specially $\mathrm{Zn}$ ) than other organic material tested (Raman et al., 1999).

Gradual release of nutrients from pressmud may be helpful in development of plants, eventually resulted in better yield. This corroborates findings of (Chauhan, 2001).

\section{Soil properties}

\section{pH, EC, ESP and Hydraulic conductivity}

Integrated use of fertilizer and organic nitrogen resulted in decrease the $\mathrm{pH}, \mathrm{EC}$ and ESP of the soil(Table 2) almost in all the treatments maximum reduction was in treatment T8 $\left(\mathrm{U}-\mathrm{N}_{30}+\mathrm{PM}-\mathrm{N}_{90}\right)$. Significant increase in hydraulic conductivity of soil was recorded with integrated use of organic and inorganic fertilizer as compared with application of urea nitrogen alone and control. Maximum improvement in hydraulic conductivity was recorded where urea + pressmud nitrogen was applied in 1:3 ratio followed by corresponding ratio of urea + water hyacinth. The improvement in hydraulic conductivity may be attributed to the improvement in soil structure. Similar observations with respect to organic materials like pressmud, Farm Yard Manure and water hyacinth on the properties of sodic soil have also been reported by (Bhagat and Verma, 1991, Verma, 1993, Kumar and Yadav, 1995, Singh et al., 2014) (Fig. 2 and 3).

\section{Organic carbon}

Maximum build up in organic carbon in soil was recorded where urea + FYM nitrogen was applied in 1:3 ratio $\left(T_{5}\right)$ followed by the same ratio of nitrogen with urea + water hyacinth and urea + prassmud. The pressmud has more raw organic material which gets further decomposed fast on their incorporation into salt affected soil leave smaller quantity of organic matter than FYM and water hyacinth. The increase in organic carbon content in soil with integrated use of organic and fertilizer nitrogen was also observed by (Verma and Bhagat, 1992).

\section{Available nitrogen}

The table 3 and figure 4 indicated that available nitrogen in soil was significantly higher in all treatments over $\mathrm{T}_{1}$ (control) and $\mathrm{T}_{2} \quad\left(\mathrm{~N}_{120^{-}}\right.$recommend $)$. The maximum available nitrogen content was recorded (116 and $118 \mathrm{~kg} \mathrm{ha}^{-1}$ ) under the treatment $\mathrm{T}_{7}(\mathrm{U}-$ $\mathrm{N}_{60}+$ PM-N $\mathrm{N}_{60}$ ) followed by treatment $\mathrm{T}_{4}(\mathrm{U}-$ $\left.\mathrm{N}_{60}+\mathrm{FYM}-\mathrm{N}_{60}\right)+$ and $\mathrm{T}_{10}\left(\mathrm{U}-\mathrm{N}_{60}+\mathrm{WH}-\mathrm{N}_{60}\right)$ 
during both the years. Pressmud proved better in reduction of soil $\mathrm{pH}$ than FYM and water hyacinth therefore, reduced volatilization loss of nitrogen reported by (Chaphale and Badole, 1999, Srivastava et al., 2016).

\section{Available phosphorus and potassium}

Available phosphorus and potassium contents in soil increased significantly with integrated use of organic sources and fertilizer over control. Integrated nitrogen treated plots also had significantly higher available $\mathrm{P}_{2} \mathrm{O}_{5}$ over the recommended close of fertilizer alone except in treatment $\mathrm{T}_{3}\left(\mathrm{U}-\mathrm{N}_{90}+\mathrm{FYM}-\mathrm{N}_{30}\right)$. The maximum available phosphorus was estimated under the treatment receiving 1:3 ratio of urea nitrogen plus pressmud $\mathrm{N}$ which was at par with respective ratio of urea nitrogen plus FYM and urea nitrogen plus water hyacinth. Similar results were found in next year of investigation. The table 3 further shows significant increase in available $\mathrm{K}_{2} \mathrm{O}$ in soil in all the treatments involving inorganic plus organic fertilizer nitrogen over the control and recommended dose of fertilizer during both the years. The maximum available $\mathrm{K}_{2} \mathrm{O}$ was observed in treatment $\mathrm{T}_{8}$
$\left(\mathrm{U}-\mathrm{N}_{30}+\mathrm{PM}-\mathrm{N}_{90}\right)$ which was at par with treatment $\mathrm{T}_{5}\left(\mathrm{U}-\mathrm{N}_{30}+\mathrm{FYM}-\mathrm{N}_{90}\right)$ and $\mathrm{T}_{11}(\mathrm{U}-$ $\mathrm{N}_{30}+\mathrm{WH}-\mathrm{N}_{90}$ ). A general increase in available $\mathrm{P}$ and $\mathrm{K}$ in post harvest soil may be ascribed to the addition of $\mathrm{P}$ and $\mathrm{K}$ through pressmud, Farm Yard Manure and water hyacinth and also their release in available form from their native water insoluble compounds in soil. These findings are in agreement with those of (Deb, 1976, Medhi et al., 1996) (Fig. 5 and 6).

\section{Available zinc}

Available zinc content in soil increased significantly in all the nitrogen treated plots over control. Recommended dose of chemical fertilizers $\left(\mathrm{T}_{2}\right)$ noticed significantly superior with respect to zinc availability in soil over all the treatments but at par with treatment $\mathrm{T}_{8}(\mathrm{U}-$ $\mathrm{N}_{30}+\mathrm{PM}-\mathrm{N}_{90}$ ). This may be due to application of $25 \mathrm{~kg} \mathrm{ZnSO} \mathrm{Zn}_{4}$ per hectare recommended dose of fertilizer which increased the available zinc in soil. The increase in available zinc in soil due to addition of organic materials in soil was also reported by (Chandra, 1979, Medhi et al., 1996) (Fig. 7).

Table.1 Effect of integrated nitrogen management on grain yield of wheat

\begin{tabular}{|c|c|c|c|}
\hline \multirow[t]{2}{*}{ S. No. } & \multirow[t]{2}{*}{ Treatment } & \multicolumn{2}{|c|}{ Grain yield $\left(q h^{-1}\right)$} \\
\hline & & $\mathbf{I}^{\text {st }}$ year & II $^{\text {nd }}$ year \\
\hline $\mathbf{T}_{1}$ & Control & 22.00 & 21.80 \\
\hline $\mathbf{T}_{2}$ & Recommended (NPK) & 34.60 & 35.70 \\
\hline $\mathbf{T}_{3}$ & $\mathrm{U}-\mathrm{N}_{90}+\mathrm{FYM}-\mathrm{N}_{30}$ & 38.60 & 39.50 \\
\hline $\mathbf{T}_{4}$ & $\mathrm{U}-\mathrm{N}_{60}+\mathrm{FYM}-\mathrm{N}_{60}$ & 40.20 & 41.60 \\
\hline $\mathbf{T}_{5}$ & $\mathrm{U}^{-\mathrm{N}_{30}}+\mathrm{FYM}-\mathrm{N}_{90}$ & 35.20 & 37.50 \\
\hline $\mathbf{T}_{6}$ & $\mathrm{U}-\mathrm{N}_{90}+\mathrm{PM}-\mathrm{N}_{30}$ & 39.00 & 39.60 \\
\hline $\mathbf{T}_{7}$ & $\mathrm{U}-\mathrm{N}_{60}+\mathrm{PM}-\mathrm{N}_{60}$ & 40.70 & 42.20 \\
\hline $\mathbf{T}_{8}$ & $\mathrm{U}-\mathrm{N}_{30}+\mathrm{PM}-\mathrm{N}_{90}$ & 35.80 & 38.30 \\
\hline $\mathbf{T}_{9}$ & $\mathrm{U}-\mathrm{N}_{90}+\mathrm{WH}-\mathrm{N}_{30}$ & 37.70 & 38.60 \\
\hline $\mathbf{T}_{10}$ & $\mathrm{U}-\mathrm{N}_{60}+\mathrm{WH}-\mathrm{N}_{60}$ & 39.10 & 40.30 \\
\hline $\mathbf{T}_{11}$ & $\mathrm{U}-\mathrm{N}_{30}+\mathrm{WH}-\mathrm{N}_{90}$ & 34.80 & 36.10 \\
\hline \multicolumn{2}{|l|}{ SEm \pm} & 1.20 & 1.25 \\
\hline \multicolumn{2}{|c|}{ CD at $5 \%$} & 3.55 & 3.70 \\
\hline
\end{tabular}


Table.2 Effect of Integrated nitrogen management on pH, EC, ESP and hydraulic conductivity

\begin{tabular}{|c|c|c|c|c|c|c|c|c|c|}
\hline \multirow[t]{2}{*}{ S. No. } & \multirow[t]{2}{*}{ Treatment } & \multicolumn{2}{|c|}{ pH (1:2:5) } & \multicolumn{2}{|c|}{$\mathrm{EC}\left(\mathrm{dSm}^{-1}\right)$} & \multicolumn{2}{|c|}{ ESP } & \multicolumn{2}{|c|}{$\begin{array}{c}\text { Hydraulic conductivity } \\
\left(\mathrm{cm} \mathrm{hr}^{-1}\right)\end{array}$} \\
\hline & & $I^{\text {st }}$ year & II $^{\text {nd }}$ year & $I^{\text {st }}$ year & II $^{\text {nd }}$ year & $I^{\text {st }}$ year & II $^{\text {nd }}$ year & $\mathrm{I}^{\text {st }}$ year & II $^{\text {nd }}$ year \\
\hline$T_{1}$ & Control & 8.71 & 8.80 & 0.36 & 0.33 & 30.43 & 32.03 & 0.28 & 0.27 \\
\hline $\mathbf{T}_{2}$ & Recommended (NPK) & 8.64 & 8.68 & 0.34 & 0.30 & 28.62 & 29.08 & 0.29 & 0.30 \\
\hline $\mathbf{T}_{\mathbf{3}}$ & U-N ${ }_{90}+\mathrm{FYM}-\mathrm{N}_{30}$ & 8.35 & 8.28 & 0.28 & 0.25 & 15.04 & 13.98 & 0.32 & 0.33 \\
\hline $\mathbf{T}_{4}$ & U-N ${ }_{60}+\mathrm{FYM}-\mathrm{N}_{60}$ & 8.22 & 8.20 & 0.27 & 0.24 & 13.80 & 13.31 & 0.33 & 0.34 \\
\hline $\mathbf{T}_{5}$ & $\mathrm{U}-\mathrm{N}_{30}+\mathrm{FYM}-\mathrm{N}_{90}$ & 8.18 & 8.12 & 0.24 & 0.22 & 13.53 & 13.12 & 0.36 & 0.38 \\
\hline $\mathbf{T}_{6}$ & $\mathrm{U}-\mathrm{N}_{90}+\mathrm{PM}-\mathrm{N}_{30}$ & 8.27 & 8.30 & 0.26 & 0.23 & 14.58 & 13.60 & 0.31 & 0.33 \\
\hline $\mathbf{T}_{7}$ & U-N ${ }_{60}+\mathrm{PM}-\mathrm{N}_{60}$ & 8.00 & 8.02 & 0.24 & 0.22 & 13.21 & 12.75 & 0.35 & 0.37 \\
\hline $\mathbf{T}_{8}$ & $\mathrm{U}-\mathrm{N}_{30}+\mathrm{PM}-\mathrm{N}_{90}$ & 7.75 & 7.76 & 0.21 & 0.19 & 12.90 & 12.13 & 0.38 & 0.40 \\
\hline $\mathbf{T}_{9}$ & U-N ${ }_{90}+\mathrm{WH}-\mathrm{N}_{30}$ & 8.40 & 8.35 & 0.28 & 0.26 & 14.65 & 14.20 & 0.34 & 0.34 \\
\hline$T_{10}$ & U-N $\mathrm{N}_{60}+\mathrm{WH}-\mathrm{N}_{60}$ & 8.23 & 8.22 & 0.26 & 0.24 & 14.28 & 13.60 & 0.35 & 0.36 \\
\hline$T_{11}$ & U-N ${ }_{30}+\mathrm{WH}-\mathrm{N}_{90}$ & 8.20 & 8.17 & 0.25 & 0.23 & 13.06 & 13.35 & 0.37 & 0.38 \\
\hline \multicolumn{2}{|l|}{$\mathrm{SEm} \pm$} & 0.059 & 0.060 & 0.006 & 0.007 & 0.627 & 0.558 & 0.007 & 0.007 \\
\hline \multicolumn{2}{|c|}{ CD at $5 \%$} & 0.175 & 0.180 & 0.0180 & 0.020 & 1.85 & 1.65 & 0.020 & 0.020 \\
\hline
\end{tabular}

Table.3 Effect of Integrated nitrogen management on organic carbon, available nitrogen, phosphorus, potassium and zinc

\begin{tabular}{|c|c|c|c|c|c|c|c|c|c|c|c|}
\hline \multirow[t]{2}{*}{ S.No. } & \multirow[t]{2}{*}{ Treatment } & \multicolumn{2}{|c|}{$\begin{array}{c}\text { Organic carbon } \\
(\%)\end{array}$} & \multicolumn{2}{|c|}{$\mathbf{N}$} & \multicolumn{2}{|c|}{$P_{2} O_{5}\left(\mathrm{~kg} \mathrm{ha}^{-1}\right)$} & \multicolumn{2}{|c|}{$\mathrm{K}_{2} \mathrm{O}\left(\mathrm{kg} \mathrm{ha}^{-1}\right)$} & \multicolumn{2}{|c|}{ Zinc (ppm) } \\
\hline & & $I^{\text {st }}$ year & II $^{\text {nd }}$ year & $I^{\text {st }}$ year & II $^{\text {nd }}$ year & $I^{\text {st }}$ year & II $^{\text {nd }}$ year & $I^{\text {st }}$ year & II $^{\text {nd }}$ year & $I^{\text {st }}$ year & $\begin{array}{l}\text { II }^{\text {nd }} \\
\text { year }\end{array}$ \\
\hline $\mathbf{T}_{1}$ & Control & 0.260 & 0.272 & 89 & 88 & 12.50 & 14.33 & 208.10 & 207.00 & 0.26 & 0.27 \\
\hline $\mathbf{T}_{2}$ & Recommended (NPK) & 0.265 & 0.275 & 96 & 98 & 17.62 & 18.32 & 215.30 & 217.00 & 0.44 & 0.46 \\
\hline $\mathbf{T}_{3}$ & $\mathrm{U}-\mathrm{N}_{90}+\mathrm{FYM}-\mathrm{N}_{30}$ & 0.296 & 0.305 & 105 & 107 & 19.78 & 20.50 & 230.80 & 231.90 & 0.29 & 0.31 \\
\hline $\mathbf{T}_{4}$ & $\mathrm{U}-\mathrm{N}_{60}+\mathrm{FYM}-\mathrm{N}_{60}$ & 0.306 & 0.316 & 112 & 113 & 23.90 & 24.43 & 240.20 & 241.37 & 0.31 & 0.34 \\
\hline $\mathbf{T}_{5}$ & U-N ${ }_{30}+\mathrm{FYM}-\mathrm{N}_{90}$ & 0.321 & 0.334 & 108 & 110 & 28.72 & 28.95 & 256.80 & 258.20 & 0.37 & 0.39 \\
\hline$T_{6}$ & $\mathrm{U}-\mathrm{N}_{90}+\mathrm{PM}-\mathrm{N}_{30}$ & 0.285 & 0.294 & 107 & 108 & 22.52 & 23.20 & 243.70 & 244.50 & 0.32 & 0.35 \\
\hline $\mathbf{T}_{7}$ & $\mathrm{U}-\mathrm{N}_{60}+\mathrm{PM}-\mathrm{N}_{60}$ & 0.298 & 0.304 & 116 & 118 & 26.32 & 27.95 & 251.60 & 253.47 & 0.37 & 0.38 \\
\hline $\mathbf{T}_{8}$ & $\mathrm{U}-\mathrm{N}_{30}+\mathrm{PM}-\mathrm{N}_{90}$ & 0.308 & 0.312 & 110 & 112 & 31.82 & 32.70 & 267.40 & 268.50 & 0.42 & 0.44 \\
\hline $\mathbf{T}_{9}$ & $\mathrm{U}-\mathrm{N}_{90}+\mathrm{WH}-\mathrm{N}_{30}$ & 0.291 & 0.302 & 105 & 108 & 21.50 & 22.30 & 233.50 & 236.23 & 0.30 & 0.31 \\
\hline $\mathbf{T}_{10}$ & $\mathrm{U}-\mathrm{N}_{60}+\mathrm{WH}-\mathrm{N}_{60}$ & 0.301 & 0.310 & 111 & 112 & 25.00 & 25.85 & 246.40 & 249.23 & 0.32 & 0.33 \\
\hline $\mathbf{T}_{11}$ & U-N $30+W H-N_{90}$ & 0.312 & 0.315 & 106 & 108 & 28.60 & 28.94 & 259.80 & 261.30 & 0.34 & 0.36 \\
\hline \multicolumn{2}{|c|}{$\mathbf{S E m} \pm$} & 0.006 & 0.008 & 2.78 & 2.93 & 1.21 & 1.34 & 3.80 & 3.85 & 0.008 & 0.011 \\
\hline \multicolumn{2}{|c|}{ CD at $5 \%$} & 0.017 & 0.023 & 8.20 & 8.67 & 3.57 & 3.95 & 11.23 & 11.35 & 0.024 & 0.031 \\
\hline
\end{tabular}


Fig.1

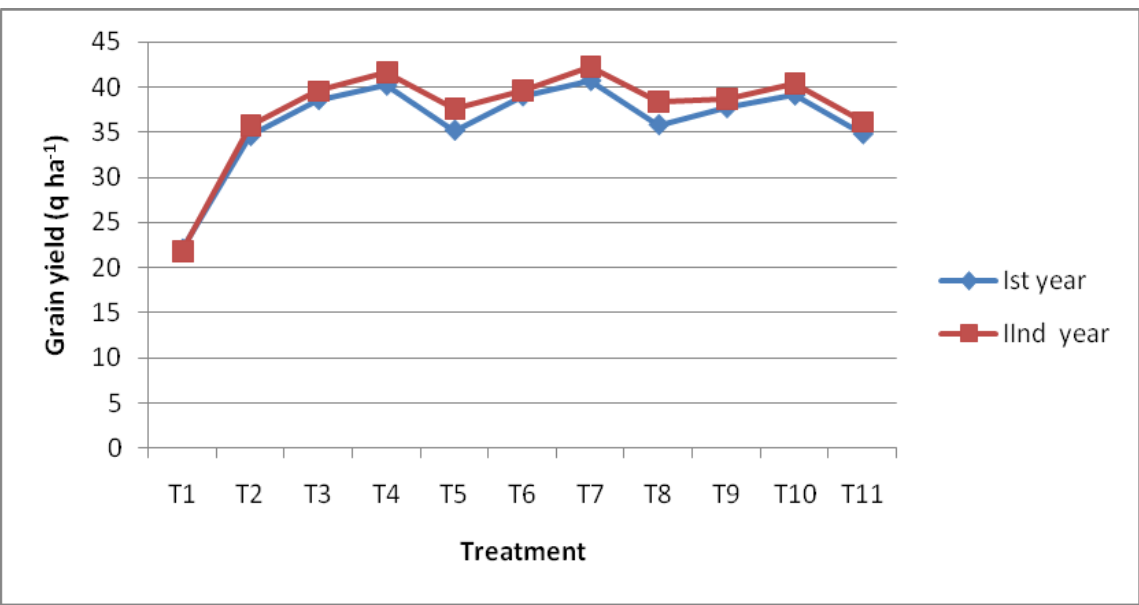

Fig.2

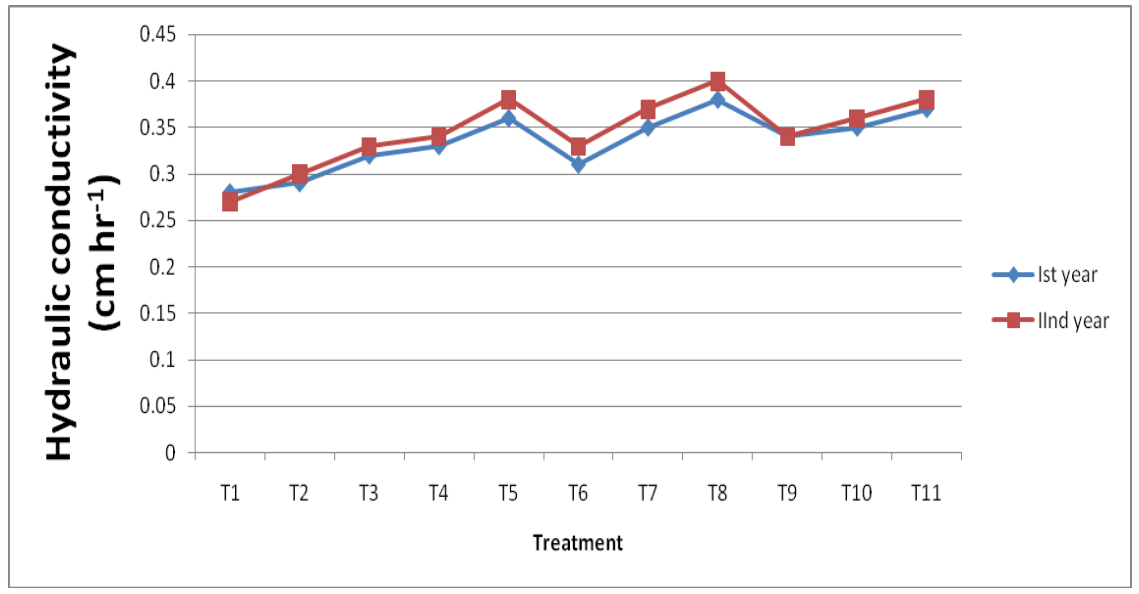

Fig.3

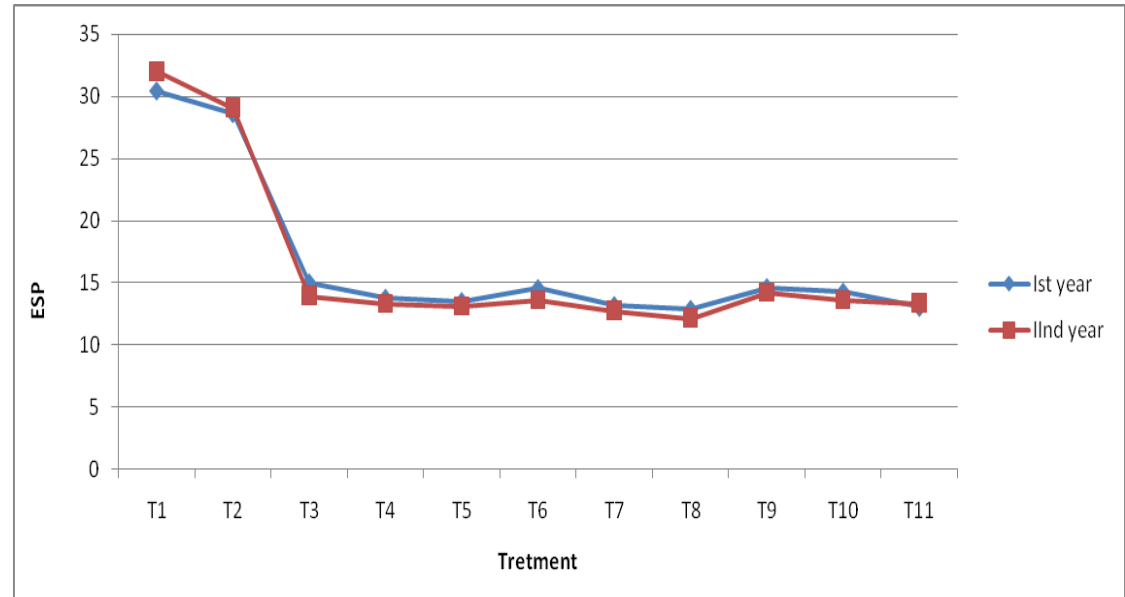


Fig.4

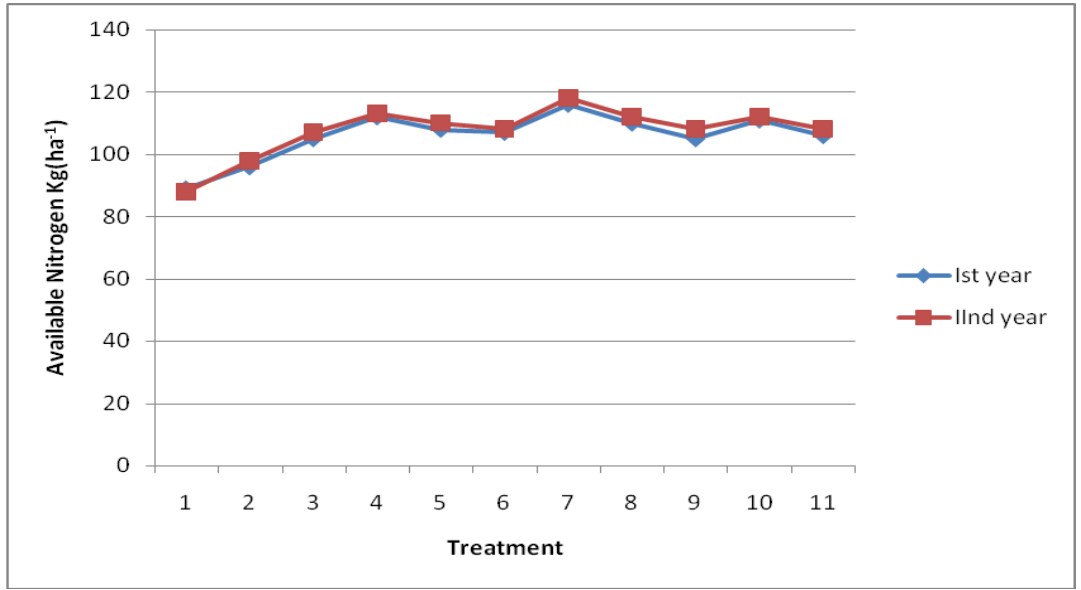

Fig.5

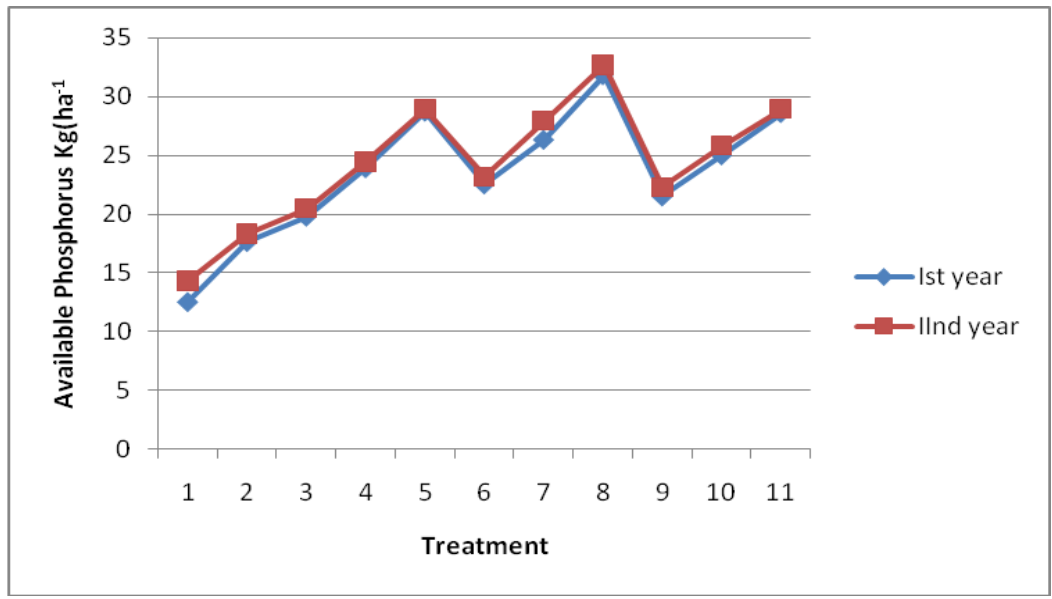

Fig.6

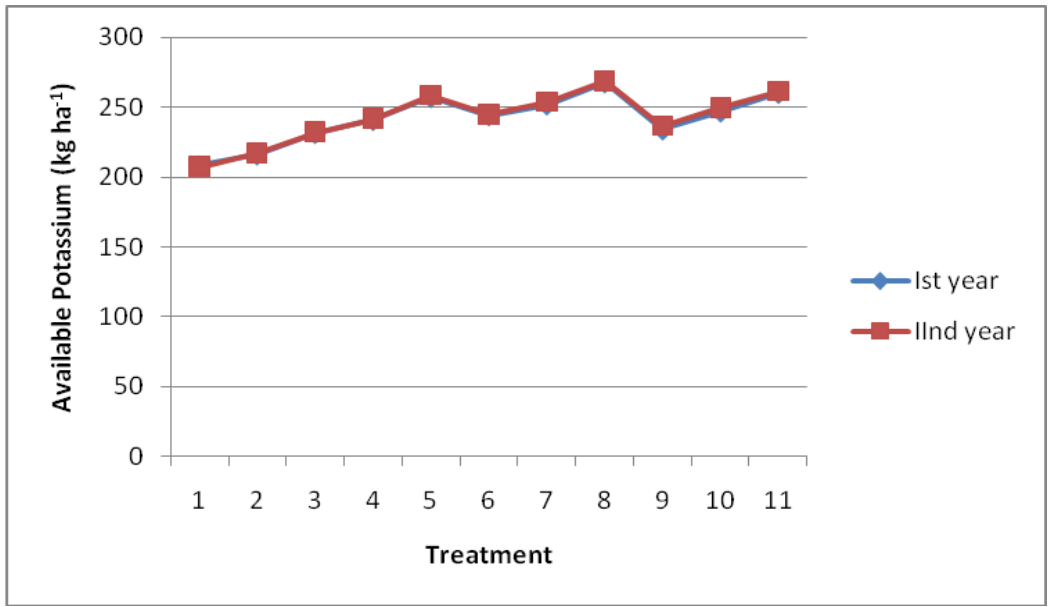


Fig.7

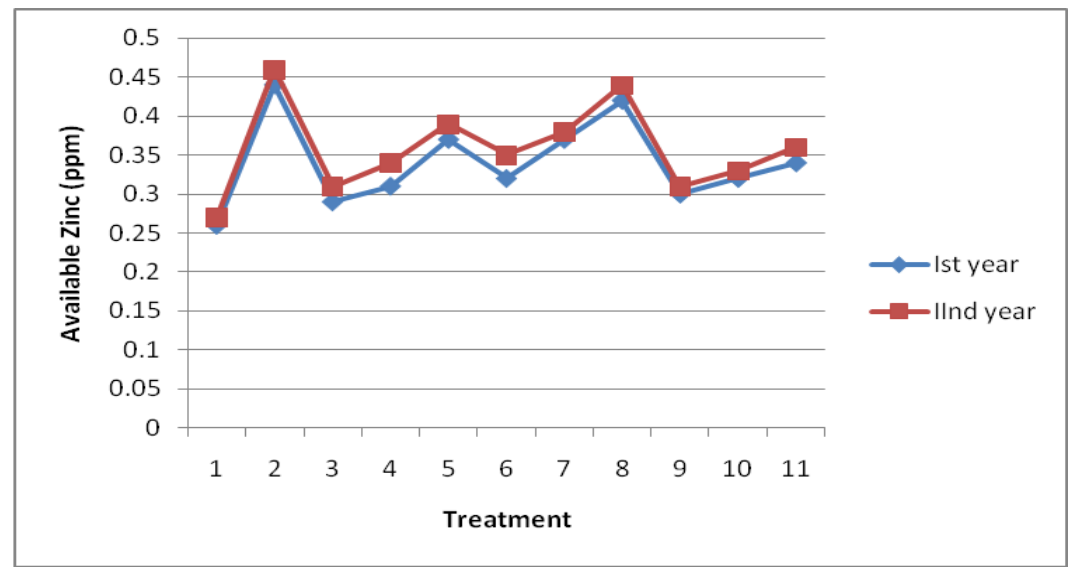

In conclusion, integrated use of nitrogen in $1: 1$ ratio through urea and pressmud was found superior in respect to crop yield against recommended dose of chemical fertilizer. However, combinations of FYM and water hyacinth with urea $\mathrm{N}$ were found at par at identical ratio. Increasing dose of organic sources of nitrogen improved properties and fertility of salt affected soil in respect to $\mathrm{pH}$, EC, ESP, hydraulic conductivity, organic carbon, available nitrogen, phosphorus, potassium and zinc.

\section{References}

Aulakh, M.S. and Grant, C.A. (2008). Integrated nutrient management for sustainable crop production. The Hawarth press, Taylor and Fransis group: New York.

Bhagat, R.M. and Verma, T.S. (1991). Impact of rice straw management on soil physical properties and wheat yield. Soil Sci., 15(2): 2108-15.

Chandra, S. (1979). Genetics and plant breeding in decade of research, CSSRI, Karnal, pp: 80-98.

Chaphale, S.D. and Badole, W.P. (1999). Effect of green manuring and NPK combinations on soil health and yield of rice (Oryza sativa). Indian $J$. Agron., 44 (3): 448-451.
Chauhan, R.P.S. 2001 Integrated use of nitrogen sources in wheat grown in partially reclaimed sodic soil. Ann. $\mathrm{Pl}$. Soil Res., 3(1): 17-25

Deb, D.L. (1976) Effect of organo mineral mixture on crop yield and soil fertility. Fertilizer News, 2 (2): 60-63.

Kumar, A. and Yadav, D.S. (1995). Use of organic manure and fertilizer in rice wheat copping system for sustainability. Indian J. Agric Sci., 65 (1) 703-707.

Medhi, B.D., Barthakur, H.P. and Barhakur, S.N. (1996). Effect of organic and inorganic sources of organic nutrients in soil and soil solution and growth of rice. J. Indian Soc. Soil Sci., 44 (4): 263-266.

Patel, T.G., Patel, K.C. and Patel, V.N. (2017). Effect of integrated nutrient management on yield attributes and yield of wheat (Triticum aestivum L.). Int. J. Chem. Studies. 5(4): 1366-1369.

Raman, S., Patel, R.G. and Jalwadia, N.M. (1999). Pressmud as a source of nutrient, amendment and wax. Fert. News, 44 (11): 29-31

Singh, N.L. (2008). A text book of soil science and fertilizer manures, Aman Publishing House, Meerut, pp: 133134.

Singh, S., Bhat, Z.A. and Rehaman, H.U. 
(2014). Influence of organic and integrated nutrient management on physicochemical properties of soil under Basmati- Wheat cropping science. The Bioscan. 9 (4): 14711478.

Srivastava, A.K. and Singh, A.K. (2016). Effect of nutrient management modules on yield of hybrid rice and nutrient availability of reclaimed alkali alluvial soil at various growth stages of rice. The Ecoscan, 10 (1 \&
2) pp: 311-316.

Verma R.S. (1993). Effect of Pyrites and Pressmud in reclamation of saline sodic soil. Bhartiya Krishi Anusandhan Patrika, 8 (1): 59-65.

Verma, T.S. and Bhagat, R.M. (1992). Impact of rice straw management practices on yield, Nitrogen uptake and soil properties in a wheat rice rotation in northern India. Fert. Res., 33 (2): 97 106.

\section{How to cite this article:}

Tripathi, S.K. 2019. Effect of Integrated Nitrogen Management on Soil Properties and Yield of Wheat in Salt Affected Soil. Int.J.Curr.Microbiol.App.Sci. 8(05): 1140-1148. doi: https://doi.org/10.20546/ijcmas.2019.805.129 